\title{
Brain Abscess due to Streptococcus Intermedius Secondary to Tetralogy of Fallot in a Child: A Case Report
}

\author{
Esra Çelik Kuzaytepe, ${ }^{1}$ Ayşe Karaaslan, ${ }^{1}$ Yasemin Akın, ${ }^{1}$ Tufan Hiçdönmez,, ${ }^{2}$ Ömer Çiftçi, ${ }^{3}$ \\ İbrahim Meriç, ${ }^{1}$ Esma Esmi, ${ }^{1}$ Melis Şirinoğlu, ${ }^{1}$ Serap Genç Yüzüak, ${ }^{1}$ Şerife Dülger ${ }^{1}$
}

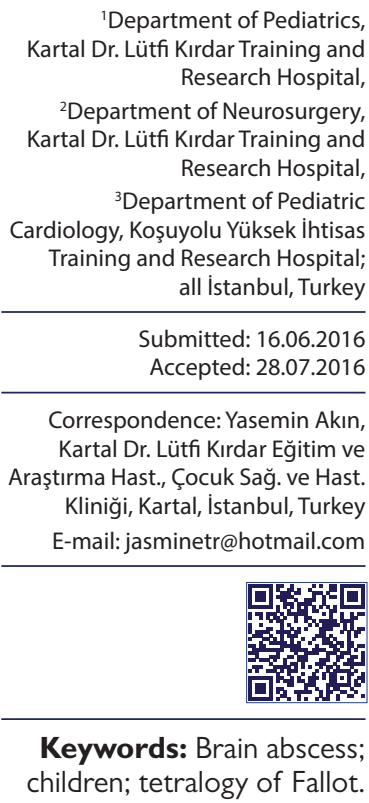

\begin{abstract}
A 10-year-old Syrian boy was admitted to emergency room with complaints of headache, vomiting, decreased level of consciousness, and imbalance when walking. On physical examination, clubbing of fingers and perioral cyanosis were observed. Cranial computed tomography examination revealed $41.55 \times 25.65 \mathrm{~mm}$ abscess formation in right occipitoparietal region. Abscess aspiration was performed. Empirical intravenous ceftriaxone and metronidazole therapy was initiated. Abscess culture yielded Streptococcus intermedius; however, urine culture yielded extended-spectrum beta-lactamase-producing Escherichia coli, and in 2 successive blood cultures, methicillin-resistant coagulase-negative staphylococci were found. Therefore, antibiotic therapy was replaced with IV vancomycin and meropenem combination. Follow-up magnetic resonance imaging was performed and abscess formulation was observed. Total abscess excision was performed. Patient was successfully treated with surgical drainage and 6 weeks of systemic antibiotic therapy. S. intermedius is found in normal oral flora, but can become pathogenic and cause potentially lethal infection in presence of underlying disease, such as cyanotic heart disease.
\end{abstract}

\section{INTRODUCTION}

Brain abscess is infectious condition that causes focal suppurative collection in the brain parenchyma. It may be seen in children at every age; however, it is most frequently encountered in children aged between 4 and 7 years. ${ }^{[1]}$ It is rare, but when observed, it induces life-threatening clinical condition. With development of imaging modalities (computed tomography $[C T]$, and subsequently magnetic resonance imaging $[M R I])$, and appropriate antibiotherapies, treatment success rates have increased. However, while morbidity and mortality rates have decreased, it is still an important cause of mortality. ${ }^{[2]}$ Brain abscess may develop as outcome of congenital heart disease, meningitis, mastoiditis, orbital cellulitis, intraoral infection, surgical intervention, or penetrating head trauma, but in $15 \%$ to $30 \%$ of cases, etiology cannot be determined. ${ }^{[3]}$ Prevalence of brain abscess in congenital cyanotic heart disease ranges between $6 \%$ and $51 \%{ }^{[4,5]}$ In $30 \%$ to $34 \%$ of patients with brain abscess, an underlying heart defect was seen. ${ }^{[6]}$ Tetralogy of Fallot (TOF) is among the most frequently seen cyanotic heart diseases that can contribute to brain abscess.

Clinical picture of children with brain abscess changes 
depending on size and location of abscess, presence of edema around abscess, and virulence of infectious agent, if infectious etiology is found. Most frequently observed symptoms are fever, headache, seizures, vomiting, and impaired consciousness. ${ }^{[7]}$

Streptococcus intermedius belongs to the Viridans streptococci group, found in normal oral and gastrointestinal flora. However, it can cause serious infectious conditions in abscess. Presently described is case of pediatric patient with diagnosis of TOF who developed brain abscess secondary to $\mathrm{S}$. intermedius infection.

\section{CASE REPORT}

A 10-year-old Syrian boy was brought to pediatric intensive care unit with complaints of headache, vomiting, clouded consciousness, and unsteady gait. Headache had persisted for 10 days. On physical examination, subfebrile body temperature, marked clubbing of fingers, perioral cyanosis, ecchymotic lips and gingiva, and grade $3 / 6$ pansystolic murmur were detected. Some of his biochemical parameters were as follows: white blood cell count: $35400 / \mathrm{mm}^{3}$, C-reactive protein: $187 \mathrm{mg} / \mathrm{L}$, and sedimentation rate: $23 \mathrm{~mm} / \mathrm{hr}$. Blood and urine cultures were obtained before lumbar puncture cranial imaging scheduled as result of detection of neurological symptoms. Cranial CT revealed lesion measuring $41.55 \times 25.65 \mathrm{~mm}$ in right occipitoparietal region, consistent with abscess formation (Figure I). Patient underwent emergency abscess aspiration in department of neurosurgery, and empirical intravenous (IV) antibiotherapy with ceftriaxone and metronidazole was initiated. S. intermedius was observed on culture of abscess material. Based on result of antibacterial susceptibility tests, maintenance of IV antibiotherapy with ceftriaxone and metronidazole was planned. However, because urine culture was positive for extended-spectrum beta-lactamase-producing Escherichia coli, and on 2 occasions blood culture was positive for methicillin-resistant coagulase-negative staphylococci, IV antibiotherapy with vancomycin and meropenem was initiated. Department of pediatric cardiology was consulted and patient was diagnosed as incomplete TOF. It was learned that patient had not had recommended cardiac surgery in Syria and had not attended follow-up cardiology visits. Our facility took over his cardiac treatment. Echocardiographic examinations were repeated 3 times and no evidence suggesting

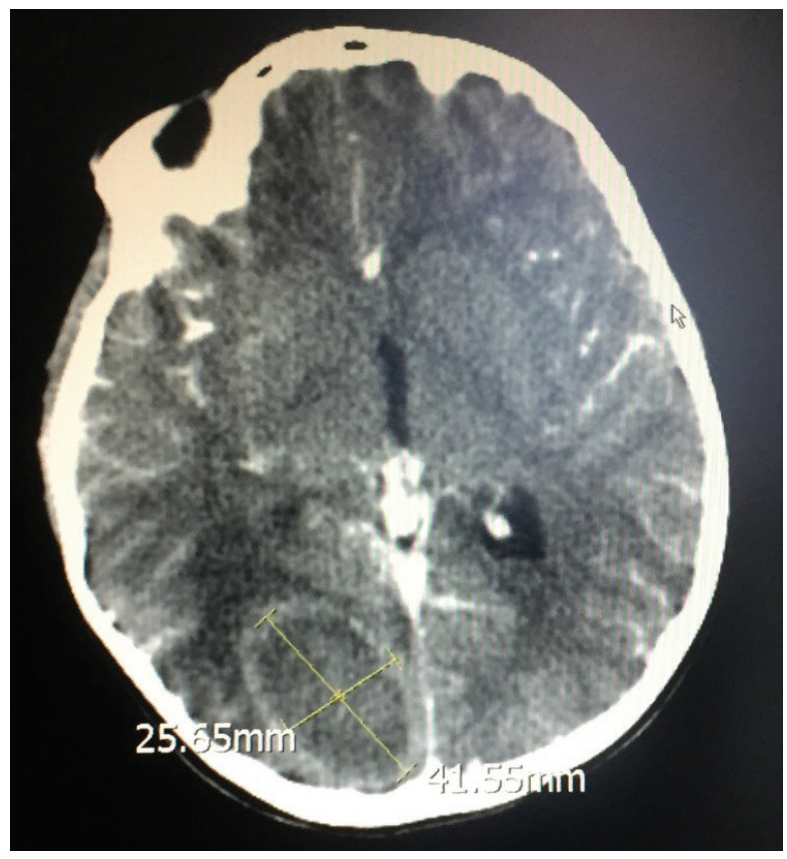

Figure 1. Brain abscess as observed in cranial computed tomography.

infective endocarditis was detected. Cranial MRI repeated at third week of treatment revealed minimal regression of abscess formation, so total excision of abscess was performed by department of neurosurgery. Brain abscess material was sent for culture a second time, and no bacterial growth was observed. Brain abscess was successfully treated with surgical intervention and systemic antibiotherapy lasting for 6 weeks. Patient was discharged and his further cardiac examinations and treatment were planned. Written informed consent was obtained from the patient who participated in this study.

\section{DISCUSSION}

Brain abscess is a rarely seen but life-threatening disease of childhood. Since the 1990s, due to development of additional diagnostic and therapeutic capabilities, prognosis has improved considerably. However, neurological deficits can be still be seen after treatment, and in some children, ventriculoperitoneal shunt may be required.

Brain abscess is an intracerebral focal infection that develops due to spread of local infection. Generally, purulent collection is seen in well-vascularized capsule. ${ }^{[8]}$ Location of abscess typically depends on source of infection. In present patient, in presence of congenital heart disease, parenchymal tissue of pari- 
etal, and occipital regions were involved. ${ }^{[9]}$ In cyanotic heart disease, bacteria cannot be filtered through pulmonary vascular bed and may spread to systemic circulation. ${ }^{[10]}$ In our case, presence of TOF as underlying cyanotic heart disease and isolation of $\mathrm{S}$. intermedius on culture of abscess material suggest this phenomenon as probable etiology.

The most frequently detected bacterial agents of brain abscess in children are aerobic and anaerobic streptococci $(60-70 \%)$, gram-negative anaerobic bacilli $(20-40 \%)$, Enterobacteriaceae $(20-30 \%)$, S. aureus $(10-15 \%)$, and fungi $(1-5 \%){ }^{[11,12]}$

As a member of S. anginosus family, $\mathrm{S}$. intermedius is a gram-positive catalase-negative coccus. It generally tends to cause infectious conditions, including abscess formation, generally seen in oral cavity, head and neck region, and abdomen. All members of $\mathrm{S}$. anginosus family produce pyrogenic exotoxin. As a distinct feature, S. intermedius produces cytolytic enzyme intermedilysin, which is thought to facilitate formation of abscess localized in liver and deep anatomical structures. ${ }^{[13]}$ Previous studies have also shown that this group of bacteria can cause development of brain abscess. ${ }^{[14-16]}$ Access to central nervous system through oral, dental, or gastrointestinal tract as result of bacteremia has been suggested. As seen in our patient, cardiac etiologies can be eliminated with echocardiographic examination. In the treatment of brain abscess caused by members of $\mathrm{S}$. anginosus family, surgical drainage of abscess and IV administration of ceftriaxone is a good treatment alternative. Concomitant use of metronidazole for synchronous anaerobic infection has also been recommended. ${ }^{[17]}$ IV treatment should be maintained for 4 to 6 weeks. Afterward, patient should be followed-up monthly for at least 3 months using imaging modalities to evaluate treatment response. ${ }^{[18]}$ In present case, treatment was completed in 6 weeks; however, patient was lost to follow-up.

In conclusion, S. intermedius, a bacterium found in normal oral flora, can become a pathogenic agent in the presence of underlying facilitatory factors, such as TOF, which can lead to development of life-threatening infection, including brain abscess.
Conflict of interest

None declared.

\section{REFERENCES}

1. Kaplan K. Brain abscess. Med Clin North Am 1985;69:345-60.

2. Mises J, Daviet F, Moussalli-Salefranque F, Sternberg B, Flandin C, Renier D. Brain abscess in the newborn infant (27 cases: initial electroclinical study, course. Rev Electroencephalogr Neurophysiol Clin 1987;17:301-8.

3. Wispelwey B, Scheld WM. Brain abscess. In: Mandell GL, Bennett JE, Dolin R, editors. Principles and Practice of Infectious Diseases. 4th ed. New York: Churchill Livingstone; 1995. p. 887-900.

4. Kumar K. Neurological complications of congenital heart disease. Indian J Pediatr 2000;67:287-91.

5. Frazier JL, Ahn ES, Jallo GI. Management of brain abscesses in children. Neurosurg Focus 2008;24:E8.

6. Agarwal A, Gergits F $3^{\text {rd }}$, Isaacson G. Metastatic intracranial abscesses of bronchopulmonary origin. Pediatr Infect Dis J 2003;22:277-80.

7. Wong TT, Lee LS, Wang HS, Shen EY, Jaw WC, Chiang CH, et al. Brain abscesses in children-a cooperative study of 83 cases. Childs Nerv Syst 1989;5:19-24.

8. Amano K, Kamano S. Cerebellar abscess due to penetrating orbital wound. J Comput Assist Tomogr 1982;6:1163-6.

9. Sáez-Llorens XJ, Umaña MA, Odio CM, McCracken GH Jr, Nelson JD. Brain abscess in infants and children. Pediatr Infect Dis J 1989;8:449-58.

10. Cochrane DD. Consultation with the specialist. Brain abscess. Pediatr Rev 1999;20:209-15.

11. Barlas O, Sencer A, Erkan K, Eraksoy H, Sencer S, Bayindir C. Stereotactic surgery in the management of brain abscess. Surg Neurol 1999;52:404-11.

12. Brouwer MC, Coutinho JM, van de Beek D. Clinical characteristics and outcome of brain abscess: systematic review and metaanalysis. Neurology 2014;82:806-13.

13. Nagamune H, Whiley RA, Goto T, Inai Y, Maeda T, Hardie JM, et al. Distribution of the intermedilysin gene among the anginosus group streptococci and correlation between intermedilysin production and deep-seated infection with Streptococcus intermedius. J Clin Microbiol 2000;38:220-6.

14. Greenlee JE. Subdural Empyema. Curr Treat Options Neurol 2003;5:13-22.

15. Petti CA, Simmon KE, Bender J, Blaschke A, Webster KA, Conneely MF, et al. Culture-Negative intracerebral abscesses in children and adolescents from Streptococcus anginosus group infection: a case series. Clin Infect Dis 2008;46:1578-80.

16. Felsenstein S, Williams B, Shingadia D, Coxon L, Riordan A, Demetriades AK, et al. Clinical and microbiologic features guiding treatment recommendations for brain abscesses in children. Pediatr Infect Dis J 2013;32:129-35.

17. Kowlessar PI, O'Connell NH, Mitchell RD, Elliott S, Elliott TS. Management of patients with Streptococcus milleri brain abscesses. J Infect 2006;52:443-50.

18. Ziai WC, Lewin JJ $3^{\text {rd }}$. Update in the diagnosis and management of central nervous system infections. Neurol Clin 2008;26:42768. 


\section{Fallot Tetralojisine Sekonder Gelişen Streptococcus Intermedius'un Neden Olduğu Beyin Apsesi: Olgu Sunumu}

Fallot tetralojisi tanıı 10 yaşında Suriyeli erkek hasta acil servise baş ağrısı, kusma, bilinç bulanıklı̆ıı ve dengesiz yürüme şikayetleriyle başvurdu. Fizik muayenede, parmaklarda belirgin çomaklaşma ve peroral siyanoz gözlendi. Hastanın yapılan kraniyal bilgiyasayarlı tomografisinde sağ oksipitoparietal bölgede 41.55×25.65 mm büyüklüğünde apse formasyonu saptandı. Apse aspirasyonu gerçekleştirildi. Ampirik olarak hastaya intravenöz (iv) seftriakson ve metronidazol tedavileri başlandı. Apsenin kültüründe Streptococcus intermedius, idrar kültüründe genişlemiş spektrumlu bata-laktaaz üreten Escherichia coli ve 2 ardışık kan kültürlerinde metisiline dirençli koagülaz-negatif stafilokoklar saptandı. Bu nedenle mevcut antibiyoterapi yerine iv vankomisin ve meropenem kombinasyonu kullanıldı. Takip sırasında manyetik rezonans görüntüleme yapıldı ve apse oluşumu gözlendi. Apse tümüyle eksize edildi. Hasta cerrahi drenaj ve 6 hafta sistemik antibiyotik tedavisiyle başarıyla tedavi edildi. Normal ağız florasında S. intermedius bulunmuş olup siyanotik kalp hastalı̆ı gibi altta yatan bir hastalık varlı̆ıında S. intermedius patojenik hale gelebilir ve potansiyel olarak ölümcül enfeksiyona neden olabilir.

Anahtar Sözcükler: Beyin apsesi; çocuk; Fallot tetralojisi. 